\title{
Foraminiferal Evidence of Late Holocene Sea-Level Change and Amerindian Site Distribution at Montague Harbour, British Columbia
}

\section{Les changements du niveau marin à l'Holocène supérieur attestés par les foraminifères et la répartition des sites amérindiens au Montague Harbour, en Colombie-Britannique Foraminiferen-Belege über die Veränderung des Meeresniveaus im späten Holozän und Verteilung der indianischen Siedlungsplätze am Montague Harbour, British Columbia}

\author{
Eduard G. Reinhardt, Norman A. Easton et R. Timothy Patterson
}

Volume 50, numéro 1, 1996

URI : https://id.erudit.org/iderudit/033073ar

DOI : https://doi.org/10.7202/033073ar

Aller au sommaire du numéro

Éditeur(s)

Les Presses de l'Université de Montréal

ISSN

0705-7199 (imprimé)

1492-143X (numérique)

Découvrir la revue

Citer cet article

Reinhardt, E. G., Easton, N. A. \& Patterson, R. T. (1996). Foraminiferal Evidence of Late Holocene Sea-Level Change and Amerindian Site Distribution at Montague Harbour, British Columbia. Géographie physique et Quaternaire, 50(1), 35-46. https://doi.org/10.7202/033073ar

\section{Résumé de l'article}

L'analyse des foraminifères et des sédiments d'une coupe stratigraphique sous-marine d'un habitat amérindien a permis d'accroître les connaissances sur les changements du niveau marin. Il semble qu'une partie de la transgression connue ait été causée par une subsidence de nature tectonique $\left(1^{\mathrm{er}}\right.$ épisode vers $3500 \mathrm{cal}$. BP et $2^{\mathrm{e}}$ épisode un peu avant $1100 \mathrm{cal}$. BP) qui a entraîné des changements environnementaux rapides consignés dans la stratigraphie. Les sédiments et les foraminifères ont en effet enregistré les changements rapides de la profondeur de l'eau. Les épisodes de subsidence, accompagnés par une transgression modérée à l'Holocène supérieur, ont provoqué la formation d'une brèche dans le chenal nord-ouest du Montague Harbour, qui a facilité la circulation des eaux et fait augmenter la salinité à l'intérieur du havre. Ce changement de salinité s'est manifesté par le remplacement du biofaciès (1) de faible salinité dominé par Cribroelphidium excavatum (Terquem, 1876) type " clavata », à la base de la coupe, par le biofaciès (2) de forte salinité dominé par Bucella tenerrima (Bandy, 1950) et Elphidiella hannai (Cushman et Grant, 1927) au sommet. Les changements du niveau marin ont forcé les Amérindiens à déménager vers l'intérieur. La datation au ${ }^{14} \mathrm{C}$ sur bois et coquille montre que la récupération de vestiges archéologiques de la culture Charles (ca 6500-3200 BP) devra se faire en eaux plus profondes. 


\section{FORAMINIFERAL EVIDENCE OF LATE HOLOCENE SEA-LEVEL CHANGE AND AMERINDIAN SITE DISTRIBUTION AT MONTAGUE HARBOUR, BRITISH COLUMBIA}

Eduard G. REINHARDT ${ }^{\star}$, Norman A. EASTON and R.Timothy PATTERSON, first and third authors: Ottawa-Carleton Geoscience Centre and Department of Earth Sciences, Carleton University, 1125 Colonel by Drive, Ottawa, Ontario K1S 5B6; second author: Department of Anthropology, Trinity College, 6 Hoskins Ave., Toronto, Ontario M5S $1 \mathrm{H} 9$.

ABSTRACT Foraminiferal and sedimentological analysis of an underwater stratigraphic section from an Amerindian habitation site at Montague Harbour, British Columbia has further documented late Holocene sea level changes. It appears that part of the documented transgression was caused by tectonic subsidence of the area (Event 1 at approx. 3500 calendar years BP and Event 2 sometime before 1100 calendar years BP) and was recognized in the stratigraphic record by rapid environmental changes. The environmental changes caused by rapid shifts in water depth were recognized through sedimentological and foraminiferal evidence. The tectonic subsidence events, coupled with gentle late Holocene transgression, caused the breaching of Montague Harbour's northwestern channel. The breaching of the channel improved water circulation and increased salinity within the harbour. The salinity changes are reflected in the shift from a low salinity Cribroelphidium excavatum (Terquem, 1876) phenotype "clavata" dominated biofacies (1) at the base of the section to a higher salinity Buccella tenerrima (Bandy, 1950) and Elphidiella hannai (Cushman and Grant, 1927) dominated biofacies (2) at the top. These sea-level changes would have eventually forced local Amerindian settlements inland. The ${ }^{14} \mathrm{C}$ dating of wood and shell, indicates that the recovery of archaeological remains of the Charles culture (ca.6500-3200 years $\mathrm{BP}$ ) requires investigation in deeper waters.
RÉSUMÉ Les changements du niveau marin à l'Holocène supérieur attestés par les foraminifères et la répartition des sites amérindiens au Montague Harbour, en ColombieBritannique. L'analyse des foraminifères et des sédiments d'une coupe stratigraphique sous-marine d'un habitat amérindien a permis d'accroître les connaissances sur les changements du niveau marin. II semble qu'une partie de la transgression connue ait été causée par une subsidence de nature tectonique $\left(1^{\text {er }}\right.$ épisode vers $3500 \mathrm{cal}$. BP et $2^{e}$ épisode un peu avant $1100 \mathrm{cal}$. BP) qui a entraîné des changements environnementaux rapides consignés dans la stratigraphie. Les sédiments et les foraminifères ont en effet enregistré les changements rapides de la profondeur de l'eau. Les épisodes de subsidence, accompagnés par une transgression modérée à l'Holocène supérieur, ont provoqué la formation d'une brèche dans le chenal nord-ouest du Montague Harbour, qui a facilité la circulation des eaux et fait augmenter la salinité à l'intérieur du havre. Ce changement de salinité s'est manifesté par le remplacement du biofaciès (1) de faible salinité dominé par Cribroelphidium excavatum (Terquem, 1876) type " clavata ", à la base de la coupe, par le biofaciès (2) de forte salinité dominé par Bucella tenerrima (Bandy, 1950) et Elphidiella hannai (Cushman et Grant, 1927) au sommet. Les changements du niveau marin ont forcé les Amérindiens à déménager vers l'intérieur. La datation au ${ }^{14} \mathrm{C}$ sur bois et coquille montre que la récupération de vestiges archéologiques de la culture Charles (ca 6500-3200 BP) devra se faire en eaux plus profondes.

\footnotetext{
Manuscrit reçu le 7 février 1995; manuscrit révisé accepté le 18 septembre 1995 * e-mail address: ereinhar@ccs.carleton.ca
}

ZUSAMMENFASSUNG ForaminiferenBelege über die Veränderung des Meeresniveaus im späten Holozän und Verteilung der indianischen Siedlungsplätze am Montague Harbour, British Columbia. Die Foraminiferen- und Sediment-Analyse eines stratigraphischen Unterwasserabschnitts von einer Indianer-Siedlung am Montague Harbour, British Columbia, hat weitere Belege über Meeresniveauwechsel im späten Holozän geliefert. Es scheint, daß ein Teil der dokumentierten Transgression durch tektonische Senkung des Gebiets verursacht wurde (Ereignis 1 um circa 3500 Kalenderjahre v.u.Z. und Ereignis 2 irgendwann vor 1100 Kalenderjahren v.u.Z.) und in dem stratigraphischen Beleg durch rasche Umweltveränderungen kenntlich wurde. Die durch schnelle Wechsel der Wassertiefe verursachten Umweltveränderungen sind durch Sediment- und Foraminiferen-Belege aufgezeichnet worden. Die Episoden tektonischer Senkung verursachten zusammen mit einer sanften Transgression im späten Holozän die Bildung einer Bresche im nordwestlichen Kanal von Montague Harbour. Die Bresche im Kanal verbesserte die Wasserzirkulation und erhöhte den Salzgehalt im Hafen. Die Veränderungen im Salzgehalt spiegeln sich im Wechsel von einer Biofazies (1) mit einem niedrigen Salzgehalt beherrscht von Cribroelphidium excavatum (Terquem, 1876) des Phänotypus "clavata" an der Basis des Schnittes, zu einer Biofazies (2) mit höherem Salzgehalt, beherrscht von Bucella tenerrima (Bandy, 1950) und Elphidiella hannai (Cushman und Grant, 1927) an der Spitze. Diese Meeresniveau-Wechsel haben wohl die örtlichen indianischen Siedlungen gezwungen, landeinwärts zu ziehen. Die ${ }^{14} \mathrm{C}$ Datierung von $\mathrm{Holz}$ und Muscheln zeigt, daß das Auffinden von archäologischen Spuren der Charles-Kultur (ca. 6500-3200 Jahre v.u.Z.) eine Suche in tieferen Wassern erfordert. 


\section{INTRODUCTION}

Micropaleontological analysis is a widely used tool within the earth sciences and has proven to be very useful for paleoenvironmental analysis. However, this approach is virtually unknown to marine archaeological researchers. Two recent studies have shown that a multidisciplinary approach (including micropaleontology and sedimentology) to marine archaeology can provide a wealth of information not normally recovered using traditional techniques. A pilot study from the ancient harbour at Caesarea, Israel successfully used foraminifera as an environmental proxy, to identify changes over the course of the harbour's history. These results significantly enhanced the archaeological interpretation (Reinhardt et al., 1994a; 1994b). Fedje (1993) and Josenhans et al. (1995) utilized a variety of microfossil groups including foraminifera, to provide data on sea-level changes that affected prehistoric colonization and settlement patterns in the Queen Charlotte Islands on the west coast of Canada.

This study analyzed foraminiferal faunal changes within a stratigraphic section recovered during underwater excavations at Montague Harbour, British Columbia to determine sea-level changes and how they affected the areal distribution of Amerindian culture types in the Montague Harbour area (Fig. 1).

\section{GEOLOGIC SETTING}

The west coast of Canada is on the leading edge of the continental margin, lying adjacent to rugged mountains. The continental shelf is very narrow with an irregular and rocky coastline characterized by deeply incised inlets, fjords and numerous offshore islands. The topography is primarily controlled by the structural trends of the Western Canadian Cordillera as modified by Pleistocene glaciation (Clague et al., 1982). The British Columbia coastline can be divided into three zones which parallel the Western Cordillera trends (Clague et al., 1982).

The first zone encompasses the eastern most mainland and adjacent islands. The second, the outer coastal zone, includes the Queen Charlotte Islands and western Vancouver Island. The third middle coastal zone where Montague Harbour is situated has low to moderate relief and includes eastern Vancouver Island and the Gulf Islands.

The Wisconsinan sea-level history of the British Columbia coast is a complex interaction between eustatic, isostatic and tectonic changes. These last two factors, which affect relative sea-level changes, may vary quite widely between the different areas of the coast (Clague et al., 1982).

Eustatic fluctuations are widely known and are the result of changes in the volume of water in the world's ocean basins due to the containment of water in continental glaciers. For example, eustatic sea level was approximately $100 \mathrm{~m}$ lower than present during the Wisconsinan glacial maximum but rose rapidly during deglaciation (Clague et al., 1982; Fairbanks, 1989; Flint, 1971).

Isostatic changes are also well documented from many glaciated areas. These changes played an important role in relative sea-level changes on the British Columbian coast. The

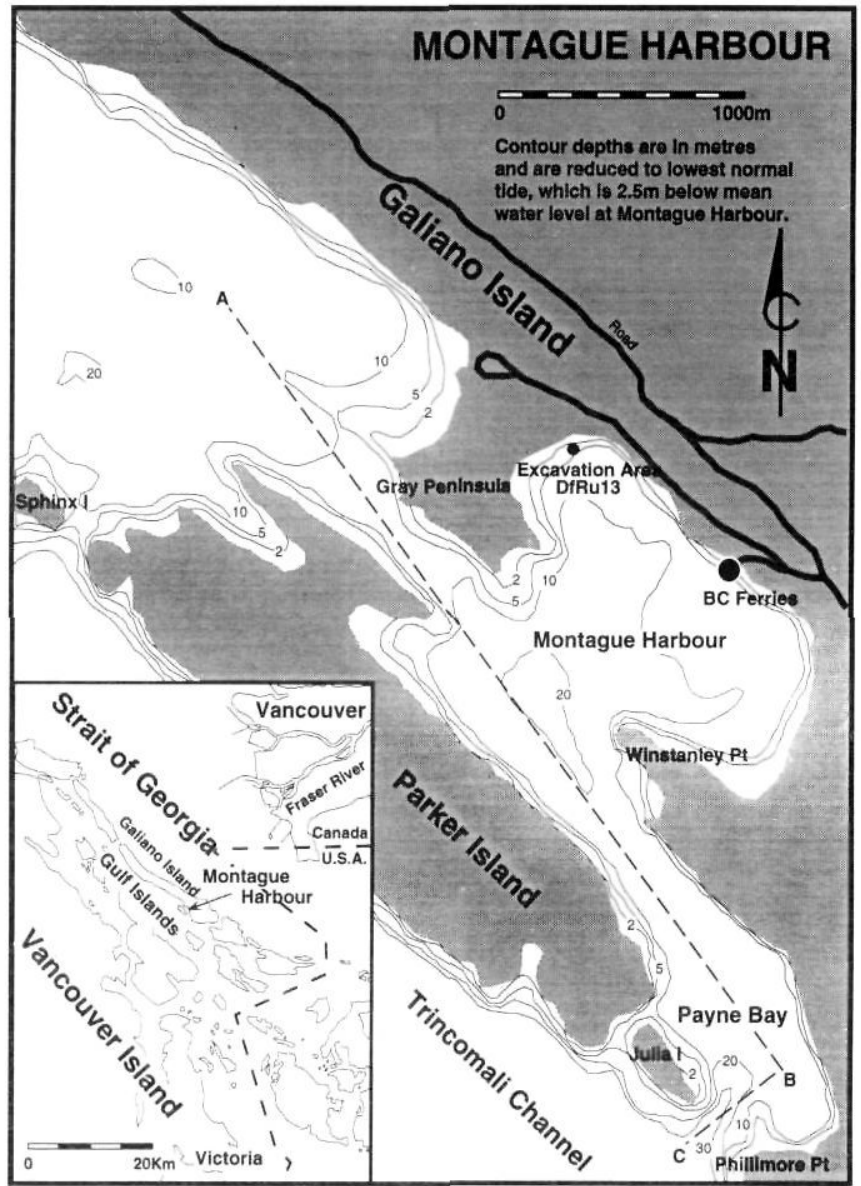

FIGURE 1. Map showing the location, physiography and bathymetry of Montague Harbour. Map was derived from Canadian Hydrographic chart no. 3473 .

Localisation, physiographie et bathymétrie du Montague Harbour (issue de la carte hydrographique du Canada $n^{\circ}$ 3473).

retreat of the Wisconsinan ice sheet caused isostatic rebound that continues to occur thousands of years after removal of the ice load (Clague et al., 1982; Flint, 1971; Josenhans et al., 1993; Luternauer et al., 1989).

The evidence of tectonically induced sea-level change, however, is in many instances hard to discern since eustatic and isostatic changes can be so large that they mask the tectonic evidence (Clague et al., 1982). However, within the last 5000 years, eustatic and isostatic sea-level changes have been minor, allowing the recognition of tectonic sea-level changes in the area (Clague et al., 1982; Mathewes and Clague, 1994). The tectonic activity is thought to be associated with the position of western British Columbia on the edge of the American lithospheric plate and its interaction with the Juan de Fuca, Explorer and Pacific plates (Monger and Price, 1979; Riddihough, 1977; Riddihough and Hyndman, 1976; Souther, 1977; Wheeler et al., 1972).

Evidence of such tectonically induced sea-level changes has recently been reported by Mathewes and Clague (1994). In that study two regional scale tectonic events at approximately 3600 and 1900 calendar years ago were recognized on the southern portion of Vancouver Island, both of which 
caused coastal subsidence. The older event displayed a pattern consistent with a large (magnitude $M \geqslant 8$ ) plate boundary earthquake on the Cascadia subduction zone (only $200 \mathrm{~km}$ due west of Montague Harbour). The younger event was also likely due to a plate boundary earthquake or a very large crustal or intraplate earthquake (Atwater, 1987; Atwater, 1992; Atwater et al., 1991; Mathewes and Clague, 1994). These two tectonically induced subsidence events were of such magnitude (one area subsided by $1-1.5 \mathrm{~m}$ ) that they are recognizable in both the micropaleontological and sedimentological record (Guilbault et al., 1994; Mathewes, 1994).

\section{ARCHAEOLOGICAL SETTING}

Numerous questions relating to the earliest human migrations on the North American continent are still unresolved. Several researchers believe that human migrations could have occurred along a coastal route (Easton, 1992a; Fedje, 1993; Fladmark, 1979; Gruhn, 1988); but this hypothesis has been difficult to prove since rising sea levels would have destroyed the coastal sites (Fladmark, 1990; Thomson, 1978). There are however, certain physiographic conditions which might allow the preservation of these important sites in a submarine environment. Flemming (1983) based on numerous preservational variables, designated Montague Harbour as one of these potential sites that would warrant investigation.

The physiography of Montague Harbour keeps the basin well protected from normal winds and extreme tidal currents preventing erosion on its western coast (Fig. 1). Shelter from the elements would have made the area attractive for settlement by early Amerindians as indicated by the numerous shell midden sites in the area (Easton and Moore, 1991). These subaerially deposited midden sites are presently being actively eroded by coastal processes indicating that relative sea level was lower in the prehistoric past (Mitchell, 1971)

The chronology of Amerindian culture types in the Strait of Georgia region is currently defined as: Old Cordilleran (ca. 9000-6500 years BP); Charles (ca. 6500-3200 years BP); Locarno Beach (ca. 3200-2400 years BP); Marpole (ca. 24001600 years BP); Strait of Georgia (ca. 1600-200 years BP); and Developed Coast Salish (post-European contact; Matson and Coupland, 1995; Mitchell, 1971; 1990). The majority of the archaeological sites found in the region have been of the Locarno Beach type and later with only a very few Charles type sites; most of which have been found inland (Easton, 1993). No coastal sites inhabited during the period between deglaciation and the Charles type culture have been found in the Georgia Strait region. This lacuna represents a real gap in the archaeological record that has been explained by rising sea levels inundating these sites (Easton, 1988; Fladmark, 1990; Thomson, 1978). Excavations at Montague Harbour, both on land and underwater, were conducted from 1989-1992 to determine whether some of the earlier cultural sites may have been preserved, at least in part, in the submarine environment (Duff, 1963; Mitchell, 1971). Over the four years of excavations more than 200 prehistoric artifacts were recovered from the submarine sediments (Easton, 1993). The purpose of this research at Montague Harbour is: (1) to increase our understanding of the spatial distribution of the various culture types with respect to fluctuating sea levels in the Strait of Georgia region; and (2) to demonstrate the value of using micropaleontological techniques in marine archaeological site analysis.

\section{STRATIGRAPHY, MACROFOSSILS AND AGE}

The sedimentology and macrofossil content of the stratigraphic section used for foraminiferal analysis has been previously described in Easton (1992b; 1993; Fig. 2). The stratigraphic units are again briefly summarized here since they are important to the interpretation. The units are described moving upward from the glacially scoured bedrock.

1. Honeycombed Clay: (2.20-2.45 m) dominated by upper littoral species (dominantly Balanus sp. (78\% of total recovered fauna) but also Macoma, Littorina, and Mytilus spp.).

2. Organic sandy silt layer: $(1.25-2.20 \mathrm{~m})$ with a high proportion of organic matter and shell material. This unit was further divided by significant upward trends of Macoma and Balanus spp. The upper portion was characterized by abundant Saxidomous spp.

3. Cobble Layer: (1.00-1.25 m) a layer with sandstone slabs that were concreted at their base. Immediately below was a densely compacted layer of sediment. Balanus spp. were associated with the sandstone slabs.

4. Pebble Layer: $(0.70-1.00 \mathrm{~m})$ a sandy silt unit with abundant pebble sized sediment and Saxidomous spp.

5. Sandy Silt Layer: $(0.00-0.70 \mathrm{~m})$ a sandy silt which contained abundant shell material including fossil and live Saxidomous and Tresus spp. towards the top of the unit.

Radiocarbon dates from the section studied have been previously reported by Easton (1991; 1992b; 1993), and are included here in Table I (all dates in the text and in Fig. 2 refer to calendar years $\mathrm{BP}$ ). Six ${ }^{14} \mathrm{C}$ dates obtained from the bottom half of the high organic unit (unit 2 - see lithological description) indicate that the terrestrial organics and one shell had dates that clustered around 6700 years BP (Fig. 2; Table I). However, a $3458 \pm 128$ years BP date from a harpoon point found within the interval of the dated organics, indicates that the other dated material was probably reworked from an older deposit. Alternatively, the point could be intrusive, having been broken off a harpoon shaft that was humanly penetrated into the older sediment. However, the thickness of the sedimentary unit that includes the dated organics is approximately $0.75 \mathrm{~m}$ thick. It would have required considerable effort on the part of the harpoon's handler to penetrate that deeply into the substrate. It is therefore more plausible that deposition of the organics and the harpoon point occurred concurrently and not before $3458 \pm 128$ years BP.

Two dates obtained from the pebble unit and one from the silty clay unit (unit 4 and 5 respectively - see lithological description) also displayed a wide temporal range. The youngest date from carbonized wood indicates that the pebble unit could not have been deposited before $1105 \pm 175$ years BP. The remaining two ${ }^{14} \mathrm{C}$ dates were derived from shell material $(1825 \pm 185$ and $2575 \pm 205$ years $B P)$ and were much older, suggesting physical and biological reworking (Fig. 2 and Table I). 


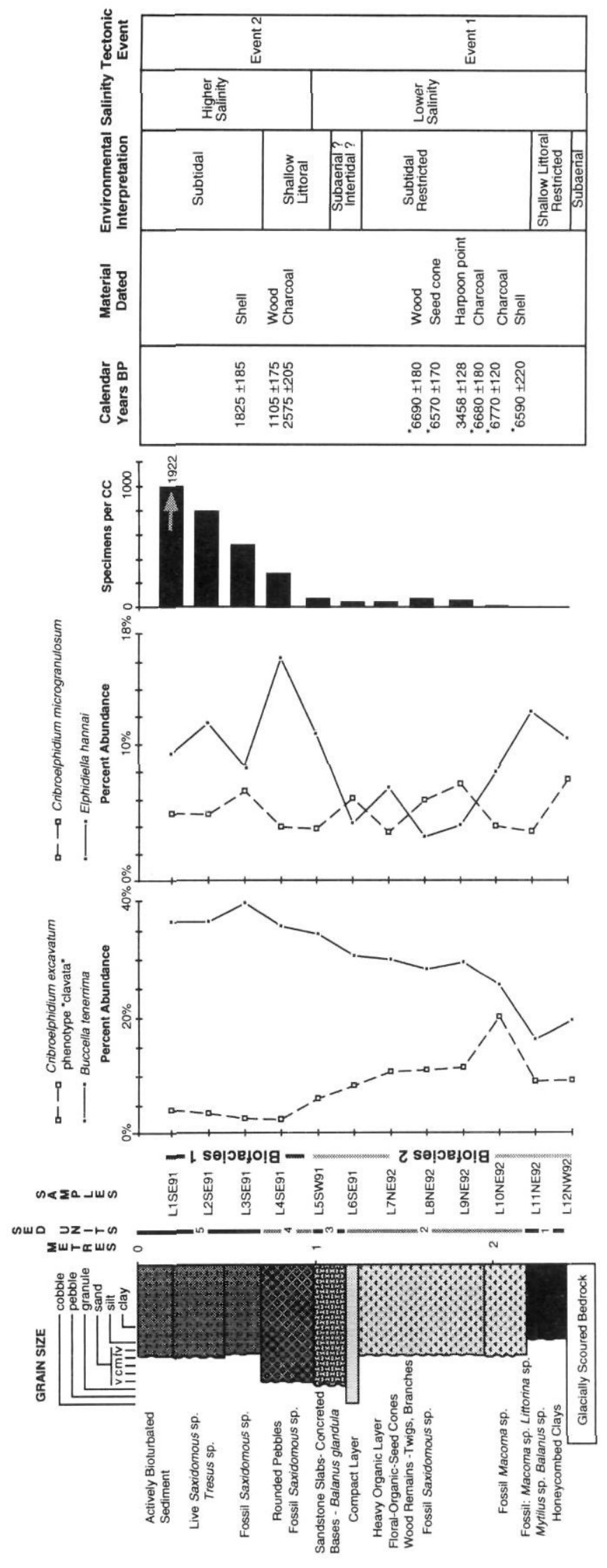

\section{METHODS}

The section chosen for foraminiferal analysis was located at Borden site number DfRu13 approximately $50 \mathrm{~m}$ offshore at a water depth of $3.5 \mathrm{~m}$ (Fig. 1). Stratigraphic correlations between the various trenches and caissons in the area have been determined during three field seasons of excavations (Easton, 1993). Sediment samples were taken at $20 \mathrm{~cm}$ intervals during underwater excavation for sedimentological and micropaleontological analysis. Subsamples of $15 \mathrm{~cm}^{3}$ were immersed in distilled water and disaggregated using a Burrell wrist action shaker. The subsamples were then rinsed under a $63 \mu \mathrm{m}$ sieve and allowed to dry under heat lamps. The foraminiferal tests (shells) were concentrated by using a heavy liquid (Carbon tetrachloride, S.G.1.56) to separate the lower density tests from the heavier sediment grains.

Species identification and counting was carried out under a binocular dissecting microscope. All specimens were illustrated using the JEOL 6400 Scanning Electron Microscope at the Scanning Electron Microscope Facilities at Carleton University. Floated samples were divided using a dry splitter to yield counts within the 500-1000 range. Some samples did not have high abundances and as a result the whole sample was examined.

The counts for each sample were changed into fractional abundances and standard errors were calculated as proposed by Patterson and Fishbein, (1989) according to the following formula:

$$
\mathrm{SX}=\left[\mathrm{Xi}_{\mathrm{i}}\left(1-\mathrm{X}_{i}\right) \mathrm{N}\right]^{1 / 2}
$$

Where $S X_{i}$ is the standard error: $X_{i}$ is the estimated fractional abundance for each $i=1,2,3 \ldots I$ species; where $I=$ the total number of species in the sample; $i$ is each species; and $N$ is the total number of specimens counted in a sample. When making $\mathrm{N}$ counts the actual fractional abundance $\mathrm{f}_{\mathrm{i}}$ lies between,

$$
X_{1}-1.96 S X_{i} \leqslant f_{i} \leqslant X_{i}+1.96 S X_{i}
$$

$95 \%$ of the time. Therefore, the $95 \%$ confidence interval on the estimated fractional abundances is $\mathrm{X}_{i} \pm 1.96 \mathrm{SX} \mathrm{X}_{i}$ (Table II).

Q-Mode cluster analysis was carried out grouping samples that had similar foraminiferal species distributions and abundances. Samples that had similar species distributions and abundances were considered to be representative of a particular environment or biofacies.

Only foraminiferal species that were deemed statistically significant were used in the Q-mode cluster analysis. The statistically significant species were those that had abundances of $1 \%$ at the $95 \%$ confidence level in at least one sample. Q-mode clustering was done on a Macintosh Ilcx computer

FIGURE 2. Stratigraphic section used for foraminiferal analysis. Sedimentary units $(1-5)$ are summarized and referred to in the text. ${ }^{14} \mathrm{C}$ dates are in calendar years BP and represent the centroid value of the $95 \%$ confidence interval reported in Table I. * indicates ${ }^{14} \mathrm{C}$ dates from reworked deposits.

Coupe stratigraphique employée pour l'analyse des foraminifères. Les unités sédimentaires (1-5) sont résumées et signalées dans le texte. Les datations sont données en cal. BP et représentent la valeur centroïde de l'intervalle de confiance de $95 \%$ reporté au tableau I. * indique que la datation provient de dépôts remaniés. 
TABLE I

Carbon Dates

\begin{tabular}{cllll}
\hline Depth $(\mathrm{cm})$ & Lab no. & ${ }^{14} \mathrm{C}$ years BP & Calendar yrs BP & Dated Material \\
\hline 60 & Beta-45195 & $2630 \pm 80$ & 2010 to 1640 & Shell \\
80 & Beta-43715 & $1180 \pm 90$ & 1280 to 930 & Wood \\
80 & Beta-47488 & $2560 \pm 70$ & 2780 to 2370 & Charcoal \\
160 & Beta-47489 & $5880 \pm 70$ & 6870 to 6510 & Wood \\
160 & Beta-47388 & $5750 \pm 80$ & 6740 to 6400 & Seed cone \\
180 & TO-4304 & $3220 \pm 70$ & 3585 to 3330 & Harpoon point-bone \\
200 & Beta-47490 & $5870 \pm 70$ & 6860 to 6500 & Charcoal \\
220 & Beta-47492 & $5930 \pm 60$ & 6890 to 6650 & Charcoal \\
220 & Beta-47491 & $6550 \pm 100$ & 6810 to 6370 & Shell \\
\hline
\end{tabular}

All depths are measured from the top of the stratigraphic section. Beta samples were analysed at Beta Analytical, Inc., 4985 SW 74 th Court, Miami, Florida, 33155. The TO sample was analyzed at the Isotrace Laboratory, University of Toronto. Calibrated ages were calculated with the bidecal data set IntCal93.14C (Stuiver and Reimer, 1993). Marine samples were adjusted for local and global reservoir correction (Delta$R=390 \pm 25$; Global reservoir $=-340$; Stuiver et al., 1986; Stuiver and Braziunas, 1993). The range represents the the $95 \%$ confidence interval based on the $1 \mathrm{~s}$ error limits of the ${ }^{14} \mathrm{C}$ age.

using the SYSTAT (1992; v.5.2) statistical software package using Ward's minimum variance method. The results of the cluster analysis on the reduced data set were then reported as Euclidean distances and arranged in a hierarchical dendrogram. The dendrogram was then used to discern sample associations or biofacies. This methodology simulates a statistically based Error-Weighted Maximum Likelihood (EWML) clustering method fully described in Fishbein and Patterson (1993).

\section{RESULTS}

\section{FORAMINIFERAL FAUNA}

The foraminiferal fauna found throughout the stratigraphic section included 14 species and phenotypes; 7 of which were deemed to be present in statistically significant numbers (Fig. 3; Tables II, III and IV). The fractional abundances of the seven species and phenotypes varied between samples as well as the overall concentration of foraminiferal tests per cubic centimetre.

The Q-mode cluster analysis delineated two distinct groups of sample associations or biofacies (Fig. 4). Biofacies 1 was represented by the top five samples (L1SE91, L2SE91, L3SE91, L4SE91, L5SW91) and Biofacies 2 by the lower seven in the stratigraphic section (L6SE91, L7NE92, L8NE92, L9SE92, L10NE92, L11NE92, L12NW92). Averaging the species fractional abundances across samples in each biofacies shows that Buccella tenerrima (Bandy, 1950) and Cribroelphidium excavatum (Terquem, 1876) phenotype "clavata" had distinctly different abundances in the two biofacies (Table III). B. tenerrima had a peak average abundance in Biofacies 1 and concomitantly $C$. excavatum phenotype "clavata" had a lower average abundance. The reverse was the case for Biofacies 2 with lower B. tenerrima and higher $C$. excavatum phenotype "clavata" average abundances.

\section{ENVIRONMENTAL CONSTRAINTS-FORAMINIFERA}

The statistically abundant species from the stratigraphic section from Montague Harbour have been linked to a variety of environments on the east and west coast of North America (Cushman and Todd, 1947; Cockbain, 1963; Scott, 1974). The foraminiferal species assemblages found throughout the stratigraphic section at Montague Harbour are all typical of a west coast shallow subtidal environment (Fig. 3).

Phenotypes of $C$. excavatum inhabit areas of brackish salinities in the modern lower latitudes of the North Atlantic (Hald and Vorren, 1987; Miller et al., 1982). As well, they have been linked to waters of slightly reduced salinities on the west coast of North America, particularly on the Fraser Delta (Patterson, 1993; Patterson and Cameron, 1991; Patterson and Luternauer, 1993; Sloan, 1980).

Elphidiella hannai (Cushman and Grant, 1927) abundances have also been linked to salinity changes. A study by Patterson and Luternauer (1993) found that abundances of C. excavatum were inversely related to water salinity compared to Buccella frigida, (Cushman, 1922) and E. hannai. As salinities increased so did the relative abundances of $E$. hannai and $B$. frigida.

Very similar species relationships were noted in the stratigraphic section at Montague Harbour and were the basis for the cluster analysis result that subdivided the section into two biofacies; Biofacies 1, including all samples in the upper part of the section and Biofacies 2, including all samples from the base of the section (Fig. 2). In Biofacies 2 the relative abundances of $C$. excavatum phenotype "clavata" were much higher than in Biofacies 1 suggesting higher relative salinities for the upper part of the stratigraphic section. As would be expected $E$. hannai was most abundant in Biofacies 1 samples. B. tenerrima was also very abundant in Biofacies 1 (Fig. 2; Table III).

B. tenerrima has been described from sandy beach and tide pool sediments and offshore to water depths of less than 
TABLE II

Foraminiferal occurrences

\begin{tabular}{|c|c|c|c|c|c|c|c|c|c|c|c|c|}
\hline Samples & L1SE91 & L2SE91 & L3SE91 & L4SE91 & L5SW91 & L6SE91 & L7NE92 & L8NE92 & L9SE92 & L10NE92 & L11NE92 & L12NW92 \\
\hline Depth(cm) & 20 & 40 & 60 & 80 & 100 & 120 & 140 & 160 & 180 & 200 & 220 & 240 \\
\hline Counts & 1802 & 1490 & 965 & 2162 & 1239 & 602 & 548 & 1183 & 780 & 127 & 57 & 68 \\
\hline Specimens / CC of Sediment & 1922 & 795 & 515 & 288 & 83 & 40 & 37 & 79 & 52 & 8 & 4 & 5 \\
\hline Astrononion gallowayi & 0.000 & 0.000 & 0.000 & 0.000 & 0.000 & 0.000 & 0.000 & 0.000 & 0.004 & 0.008 & 0.000 & 0.000 \\
\hline Std. Error \pm & 0.000 & 0.000 & 0.000 & 0.000 & 0.000 & 0.000 & 0.000 & 0.000 & 0.004 & 0.015 & 0.000 & 0.000 \\
\hline Buccella frigida & 0.054 & 0.032 & 0.036 & 0.045 & 0.065 & 0.110 & 0.036 & 0.096 & 0.076 & 0.055 & 0.018 & 0.015 \\
\hline Std. Error \pm & 0.010 & 0.009 & 0.012 & 0.009 & 0.014 & 0.025 & 0.016 & 0.017 & 0.019 & 0.040 & 0.034 & 0.029 \\
\hline Buccella tenerrima & 0.360 & 0.360 & 0.391 & 0.352 & 0.340 & 0.302 & 0.296 & 0.280 & 0.291 & 0.252 & 0.158 & 0.191 \\
\hline Std. Error \pm & 0.022 & 0.024 & 0.031 & 0.020 & 0.026 & 0.037 & 0.038 & 0.026 & 0.032 & 0.076 & 0.095 & 0.093 \\
\hline Buliminella elegantissima & 0.001 & 0.003 & 0.002 & 0.001 & 0.001 & 0.000 & 0.000 & 0.004 & 0.003 & 0.000 & 0.000 & 0.000 \\
\hline Std. Error \pm & 0.002 & 0.003 & 0.003 & 0.001 & 0.002 & 0.000 & 0.000 & 0.004 & 0.004 & 0.000 & 0.000 & 0.000 \\
\hline Cassidulina bradshawi & 0.000 & 0.000 & 0.000 & 0.000 & 0.000 & 0.000 & 0.000 & 0.000 & 0.000 & 0.008 & 0.000 & 0.000 \\
\hline Std. Error \pm & 0.000 & 0.000 & 0.000 & 0.000 & 0.000 & 0.000 & 0.000 & 0.000 & 0.000 & 0.015 & 0.000 & 0.000 \\
\hline Cribroelphidium excavatum & & & & & & & & & & & & \\
\hline phenotype "clavata" & 0.038 & 0.033 & 0.024 & 0.022 & 0.057 & 0.080 & 0.104 & 0.107 & 0.110 & 0.197 & 0.088 & 0.088 \\
\hline Std. Error \pm & 0.009 & 0.009 & 0.010 & 0.006 & 0.013 & 0.022 & 0.026 & 0.018 & 0.022 & 0.069 & 0.073 & 0.067 \\
\hline Cribroelphidium excavatum & & & & & & & & & & & & \\
\hline phenotype "lidoensis" & 0.334 & 0.313 & 0.335 & 0.334 & 0.343 & 0.316 & 0.356 & 0.315 & 0.229 & 0.291 & 0.211 & 0.265 \\
\hline Std. Error \pm & 0.022 & 0.024 & 0.030 & 0.020 & 0.026 & 0.037 & 0.040 & 0.026 & 0.030 & 0.079 & 0.106 & 0.105 \\
\hline Cribroelphidium foraminosum & 0.065 & 0.095 & 0.063 & 0.044 & 0.049 & 0.090 & 0.102 & 0.107 & 0.173 & 0.071 & 0.368 & 0.147 \\
\hline Std. Error \pm & 0.011 & 0.015 & 0.015 & 0.009 & 0.012 & 0.023 & 0.025 & 0.018 & 0.027 & 0.045 & 0.125 & 0.084 \\
\hline Cribroelphidium microgranulosum & 0.048 & 0.048 & 0.065 & 0.039 & 0.037 & 0.060 & 0.035 & 0.058 & 0.071 & 0.039 & 0.035 & 0.074 \\
\hline Std. Error \pm & 0.010 & 0.011 & 0.016 & 0.008 & 0.011 & 0.019 & 0.015 & 0.013 & 0.018 & 0.034 & 0.048 & 0.062 \\
\hline Elphidiella hannai & 0.092 & 0.114 & 0.083 & 0.162 & 0.107 & 0.042 & 0.068 & 0.031 & 0.040 & 0.079 & 0.123 & 0.103 \\
\hline Std. Error \pm & 0.013 & 0.016 & 0.017 & 0.016 & 0.017 & 0.016 & 0.021 & 0.010 & 0.014 & 0.047 & 0.085 & 0.072 \\
\hline Lobatula fletcheri & 0.000 & 0.000 & 0.000 & 0.000 & 0.000 & 0.000 & 0.000 & 0.000 & 0.001 & 0.000 & 0.000 & 0.000 \\
\hline Std. Error \pm & 0.000 & 0.000 & 0.000 & 0.000 & 0.000 & 0.000 & 0.000 & 0.000 & 0.003 & 0.000 & 0.000 & 0.000 \\
\hline Quinqueloculina sp. & 0.006 & 0.002 & 0.000 & 0.000 & 0.002 & 0.002 & 0.004 & 0.002 & 0.003 & 0.000 & 0.000 & 0.000 \\
\hline Std. Error \pm & 0.003 & 0.002 & 0.000 & 0.001 & 0.002 & 0.003 & 0.005 & 0.002 & 0.004 & 0.000 & 0.000 & 0.000 \\
\hline Rosalina columbiensis & 0.001 & 0.000 & 0.000 & 0.000 & 0.000 & 0.000 & 0.000 & 0.000 & 0.000 & 0.000 & 0.000 & 0.000 \\
\hline Std. Error \pm & 0.002 & 0.000 & 0.000 & 0.000 & 0.000 & 0.000 & 0.000 & 0.000 & 0.000 & 0.000 & 0.000 & 0.000 \\
\hline Trochammina charlottensis & 0.000 & 0.000 & 0.001 & 0.000 & 0.000 & 0.000 & 0.000 & 0.000 & 0.000 & 0.000 & 0.000 & 0.000 \\
\hline Std. Error \pm & 0.000 & 0.000 & 0.002 & 0.000 & 0.000 & 0.000 & 0.000 & 0.000 & 0.000 & 0.000 & 0.000 & 0.000 \\
\hline
\end{tabular}

Foraminiferal occurrences from the stratigraphic section from Montague Harbour. The occurrences of the various foraminiferal species in each sample are listed as fractional abundances. "Std. Error \pm " refers to the standard error which when added and subtracted from the species fractional abundance gives the $95 \%$ confidence interval. "Depth" refers to the position of the sample relative to the top of the stratigraphic section. "Counts" indicates the number of specimens quantified and "specimens/ CC of sediment" refers to the concentration of foraminiferal specimens in one cubic centimeter of sediment. 

foraminosum (Cushman, 1939) $X$ Wissler, 1927) X 150: 3) Buccella frigida (Cushman, 1922) X 170.

FIGURE 3. 1) Cribroelphidium 130 ; 2) Cribroelphidium microgranulosum (Galloway and tenerrima (Bandy, 1950) X 150: 4) Cribroelphidium excavatum (Terquem, 1876) phenotype "lidoensis" X 100; 5) Cribroelphidium excavatum (Terquem, 1876) phenotype "clavata" $X 230$ ); 6) Elphidiella hannai (Cushman and Grant, 1927) X 95; 7) Buccella

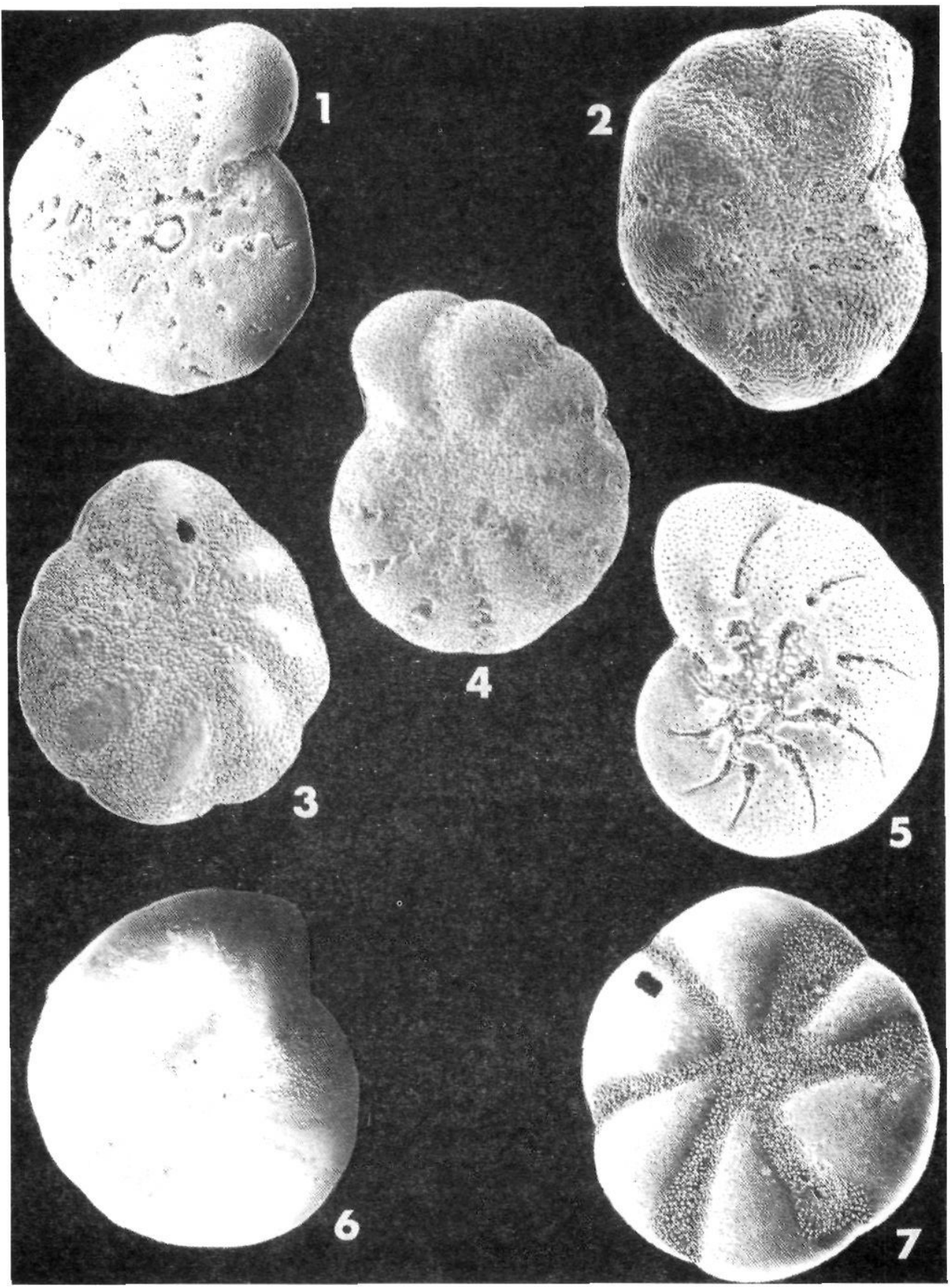

TABLE III

A listing of the statistically significant foraminiferal species; their mean fractional abundances across samples in each biofacies and their standard deviations

\begin{tabular}{|c|c|c|c|c|}
\hline & Biofacies 1 & Std & Biofacies 2 & Std \\
\hline Buccella frigida & 0.05 & 0.01 & 0.06 & 0.04 \\
\hline Buccella tenerrima & 0.36 & 0.02 & 0.25 & 0.06 \\
\hline $\begin{array}{l}\text { Cribroelphidium excavatum } \\
\text { phenotype "lidoensis" }\end{array}$ & 0.33 & 0.01 & 0.28 & 0.05 \\
\hline $\begin{array}{l}\text { Cribroelphidium excavatum } \\
\text { phenotype "clavata" }\end{array}$ & 0.03 & 0.01 & 0.11 & 0.04 \\
\hline Cribroelphidium foraminosum & 0.06 & 0.02 & 0.15 & 0.10 \\
\hline Cribroelphidium microgranulosum & 0.05 & 0.01 & 0.05 & 0.02 \\
\hline Elphidiella hannai & 0.11 & 0.03 & 0.07 & 0.03 \\
\hline
\end{tabular}


TABLE IV

Faunal List $t^{*}$

Astrononion gallowayi Loeblich and Tappan, 1953.

Buccella frigida (Cushman, 1922), [Pulvinulina].

Buccella tenerrima (Bandy, 1950), [Rotalia].

Buliminella elegantissima (d'Orbigny, 1839), [Bulimina].

Cassidulina bradshawi Uchio, 1960.

Cribroelphidium excavatum (Terquem, 1876) phenotype "clavata", [Polystomella].

Cribroelphidium excavatum (Terquem, 1876) phenotype "lidoensis",

[Polystomella].

Cribroelphidium foraminosum (Cushman, 1939), [Elphidium hughesi

Cushman and Grant, var.].

Cribroelphidium microgranulosum (Galloway and Wissler, 1927),

[Themeon decipiens].

Elphidiella hannai (Cushman and Grant, 1927), [Elphidium].

Lobatula fletcheri (Galloway and Wissler, 1927), [Cibicides].

Quinqueloculina sp.

Rosalina columbiensis (Cushman, 1925), [Discorbis].

Trochammina charlottensis Cushman, 1925

* The observed species are listed alphabetically and only the author and year of description is indicated. In cases where the present generic designation differs from the original, the original genus name is provided in square brackets at the end.

$12 \mathrm{~m}$, from Baja, California to Washington (Cooper, 1961; Lankford and Phleger, 1973). B. frigida and B. tenerrima differ only slightly morphologically ( $B$. tenerrima has a sharp keel around its periphery) and probably share similar life modes and salinity requirements although $B$. frigida is typically found at greater water depths. At Montague Harbour, B. tenerrima populations exhibit a clear inverse relationship with $C$. excavatum phenotype "clavata" populations in samples from L1 to L10 providing strong evidence that salinity is a primary control in these biofacies (Figs. 2 and 5).

C. microgranulosum (Galloway and Wissler, 1927) has not been ascribed salinity preferences, although it prefers shallow water from $0-12 \mathrm{~m}$ and is most common in tide pools and beach sediments (Barrick et al., 1989). Constant abundances of $C$. microgranulosum throughout the section at Montague Harbour suggests that the harbour has remained relatively shallow throughout the interval studied (within 0-12 m; Fig. 2; Table III).

The number of specimens per $\mathrm{cc}$ of sediment increased significantly at the Biofacies 1 and 2 boundary and may reflect a change in sedimentation rate or perhaps a change in productivity (Fig. 2). The increased sedimentation rate seems to be the dominant control, however, as the ${ }^{14} \mathrm{C}$ dates for the Biofacies 2 interval are closely clustered (6700 years BP). The relatively high sedimentation rate during deposition of the lower part of the section (Biofacies 2) seems to have caused the dilution of the foraminiferal tests. Conversely, a decreased sedimentation rate and/or an increase in productivity in the upper part of the section (Biofacies 1) may have caused an increased concentration of foraminiferal tests in the sediment.

Samples $\mathrm{L} 11$ and $\mathrm{L} 12$ deviated slightly from the character of Biofacies 2. These two samples had abnormally high abundances of $E$. hannai, all specimens of which were abraded

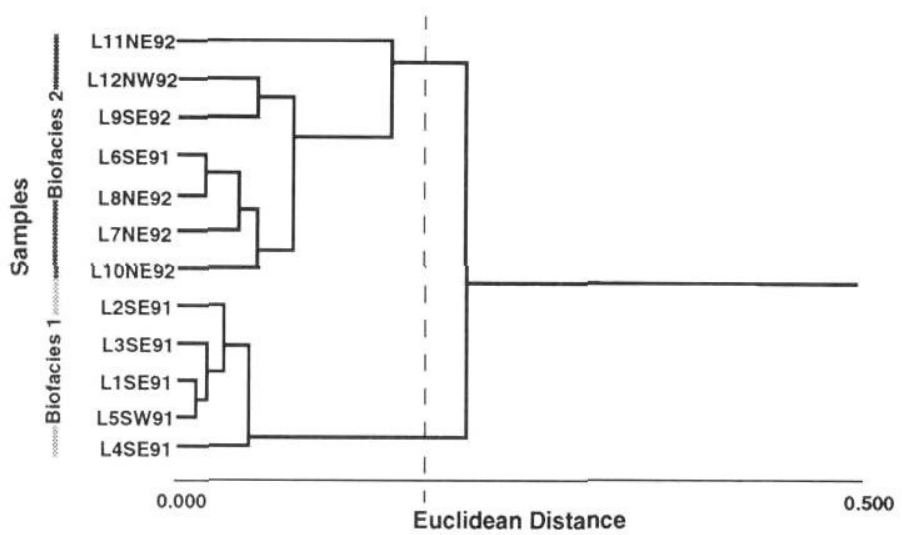

FIGURE 4. Hierarchical Q-mode dendrogram (Ward's minimum variance method) showing the two clusters that were given biofacies designations. Resemblance coefficients are Euclidean distances.

Dendrogramme hiérarchique en mode $Q$ (selon la méthode de variance minimale de Ward) montrant les groupes qui ont été désignés comme étant des biofaciès. Les coefficients de ressemblance sont des distances euclidiennes.

and fragmented. Since E. hannai is relatively large and robust, the high abundances of this species in these samples is likely due to it being preferentially preserved (Wetmore, 1987). The concentration of foraminiferal tests in these two samples was also very low compared to the other samples in Biofacies 2. This suggests, based on preservation of the observed foraminiferal tests, that taphonomic destruction produced the lower foraminiferal densities in samples L11 and L12.

\section{DISCUSSION}

\section{PHYSIOGRAPHIC CHANGES}

Changes to the physiography of the harbour and, in particular, changes in the bathymetry of the channels connecting the harbour to the open ocean resulted in the observed salinity changes within Montague Harbour. A transect showing the bathymetry through the center of the harbour and the two channels is shown in Figure 6. The maximum depth of the northwestern channel is approximately $5 \mathrm{~m}$ (depths are measured from the lowest normal tide, Figs. 1 and 6). The southeastern channel is much deeper at approximately $12 \mathrm{~m}$. Marine deposition at the studied site did not occur until relative sea level rose to $6 \mathrm{~m}$ below its present position. Assuming that local topography has not significantly changed, the southeast channel at this point would have been open to the sea. However, the northwest channel would not have been open, creating a partially restricted embayment. It is also likely that the channel initially contained significantly more glacial sediment, creating a higher barrier to the outside ocean. Rising sea levels eventually eroded this barrier away, resulting in better circulation and higher salinities (Biofacies 1).

\section{EVIDENCE OF TECTONISM AT MONTAGUE HARBOUR}

A combination of isostatic and eustatic changes probably contributed to the eventual breaching of the northwest channel and the environmental change within Montague Harbour. However, there is regional evidence suggesting that tectonism 
also played a role. The tectonism caused rapid episodic subsidence events that overprinted the evidence of a gradual transgression in the area (Clague et al., 1982; Mathewes and Clague, 1994). Mathewes and Clague (1994) documented two tectonic events that caused subsidence on southeastern Vancouver Island, and it seems that at least one is also recorded in the section at Montague Harbour.

\section{a) Tectonic Event 1}

The base of the section ( $6 \mathrm{~m}$ below sea level - from lowest normal tide) was comprised of glacially scoured bedrock (Fig. 2). Sometime during or after glaciation, silt and clays were deposited on the bedrock (L11, L12). Subsequent erosion of this silt and clay produced distinct "honeycomb" sedimentary features (Easton, 1993). These features were then infilled with nearshore shell material. This silt/clay unit was not deposited in very deep water as the contained foraminiferal fauna is characteristic of shallow water. The exact foraminiferal content of the silt/clay unit could not be determined since the samples include both shell and sediment material.

The shell material within and above the honeycombed clays contained various fossils of shallow water to intertidal organisms such as Macoma, Littorina, Mytilus and Balanus spp. The foraminiferal fauna of this unit had high fractional abundances of heavily eroded and fragmented specimens of the robust foraminiferal species E. hannai and additionally, the samples had low foraminiferal concentrations. Both microfossil and macrofossil evidence suggest nearshore reworking and perhaps a supralittoral environment. This nearshore environment was likely created by rising sea level (to within 5.5-6 $\mathrm{m}$ below present) that occurred sometime after 5500 years BP due to residual isostatic responses to deglaciation and possibly tectonic changes (Clague et al., 1982).
FIGURE 5. Plot of fractional abundances of $C$. excavatum phenotype "clavata" vs $B$. terrenima showing inverse relationship with samples L1-L10. Samples were not included in the regression analysis as they are anomalous values.

Graphique de l'abondance fractionnaire de $\mathrm{C}$. excavatum type "clavata" sur celle de B. terrenima montrant des relations inverses avec les échantillons L1 $L 10$. Les échantillons $L 11$ and $L 12$ n'ont pas été inclus dans l'analyse de régression car ils représentent des valeurs irrégulières.

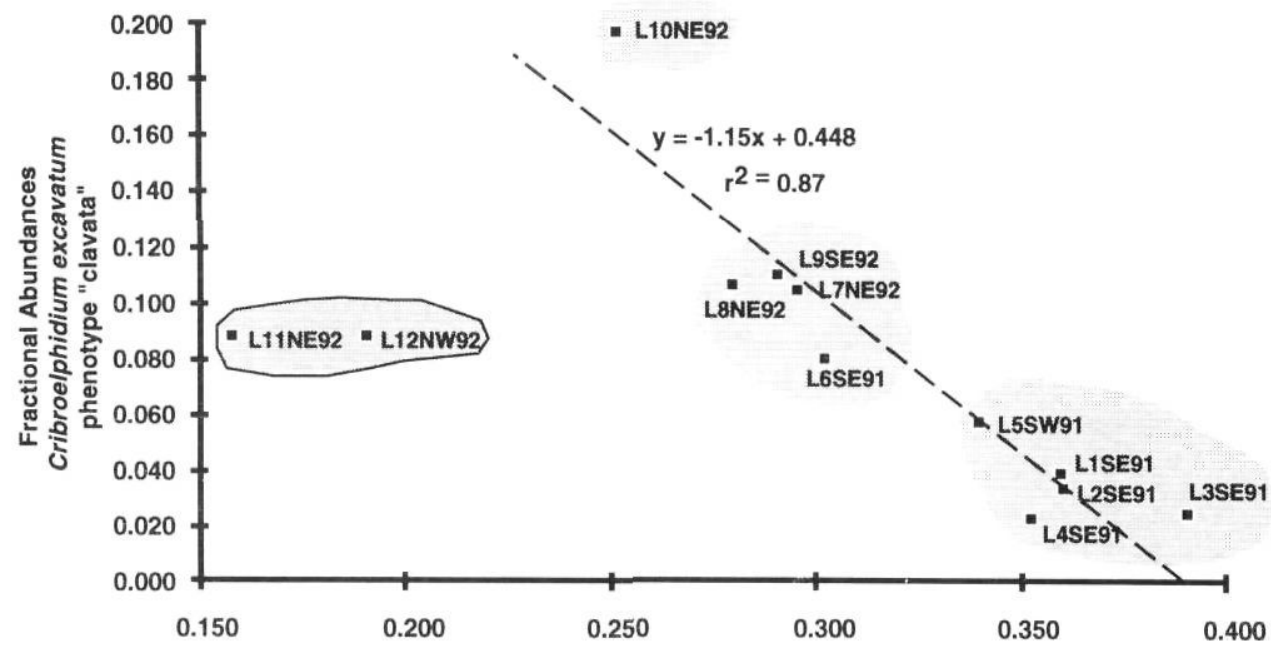

Fractional Abundances Buccella tenerrima

m.s.l.

10

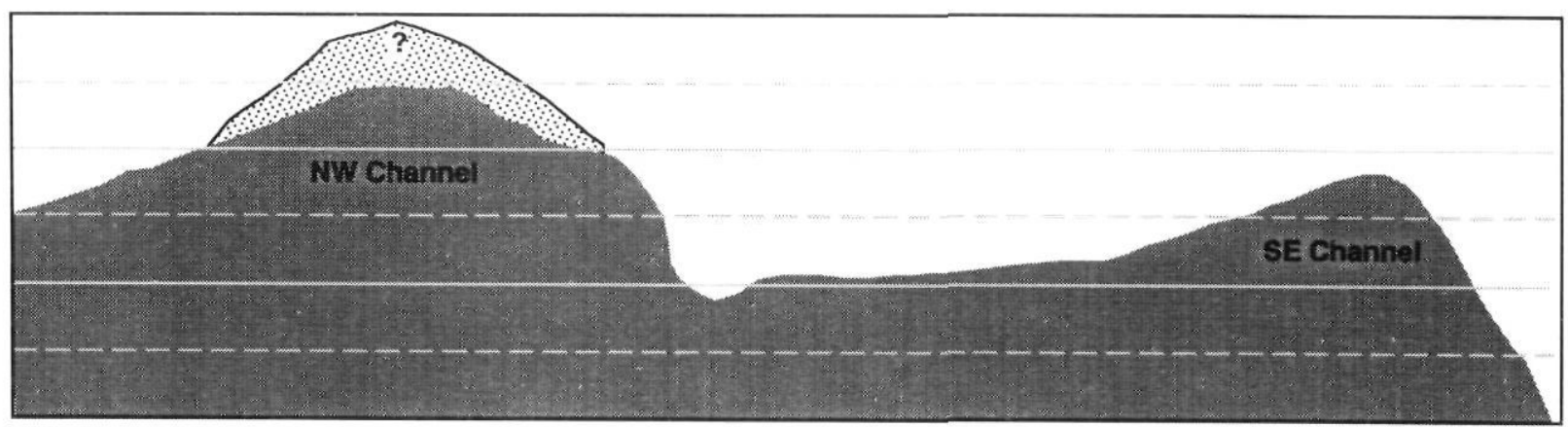

30

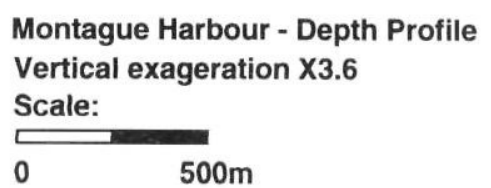

FIGURE 6. Bathymetric cross section through Montague Harbour. Letters refer to the path of the cross section indicated in Figure 1.
Coupe bathymétrique transversale du Montague Harbour. Les lettres se rapportent au transect identifié à la figure 1. 
Our Tectonic Event 1 was marked by the stratigraphic transition from nearshore intertidal (supralittoral?) deposits to a thick overlying unit characterized by abundant organic matter and a foraminiferal fauna typical of a subtidal environment (Unit 2; 220-135 cm; Fig. 2). The low concentrations of foraminifera, the high concentration of organic matter and the distribution of the ${ }^{14} \mathrm{C}$ dates suggest a rapid sea level change (subsidence approximately 1-1.5 m). This rapid sea level change resulted in a rapid shift from a nearshore and possibly supralittoral environment to a subtidal one. The sea-level change also caused the erosion of older terrestrial deposits and rapid sediment burial. However, the subsidence event was not large enough to cause the breaching of the northwest channel. Montague Harbour still remained a quiet embayment which allowed the preservation of abundant organic matter and the accretion of sediments. The $3458 \pm 128$ years BP harpoon date from within this interval (Fig. 2; Table I) is consistent with the tectonic subsidence event $1(\sim 3600$ years BP) of Mathewes and Clague (1994). Dates obtained from the organic matter surrounding the harpoon point are closely clustered around 6700 years BP suggesting that they were deposited quickly and probably from a previous deposit. The dates obtained from the organic matter are also inconsistent with the sea-level curve proposed by Clague et al. (1982) for the Victoria-Gulf Islands area which indicates that sea-level was -10 to $-12 \mathrm{~m}$ lower than present at 6700 years BP. There is no evidence of such a dramatically lower sealevel through this interval at Montague Harbour. An age estimate of 3500 years BP (based on the harpoon point) for a sea-level that was approximately -5 to $-5.5 \mathrm{~m}$ lower than present is more consistent with the Clague et al. (1982) curve.

Overlaying this high organic matter unit was a dense compact layer overlain in turn by sandstone slabs concreted with barnacles (Unit 3; 100-125 cm; Easton, 1993). Based on excavation evidence (Easton, 1993), these two units were interpreted to have been created by calichification due to subaerial exposure. Subaerial exposure of the site may have been caused by rapid sediment deposition resulting in progradation of the shoreline out into the still restricted embayment, possibly accelerated by human shell midden formation. Alternatively, a localized small scale uplift event could also explain the change from subaqueous to subaerial conditions (Guilbault et al., 1995).

\section{b) Tectonic Event 2}

Evidence for a second tectonic event at Montague Harbour seems to be distinct, but the timing is not entirely consistent with Mathewes and Clague's (1994) Tectonic Event 2.

The rounded pebble unit (Unit 4; 70-100 cm) indicates a return to subaqueous conditions (shallow littoral?) and the beginning of a higher salinity environment at the site (Biofacies 1; Fig. 2). By this time the breaching and the opening of the NW channel was complete resulting in better circulation of marine water within the embayment.

The high concentration of rounded pebbles in this unit may have derived from glacial till eroded from land into the nearshore environment as sea-level rose. The sharp transi- tion from subaerial exposure to a nearshore possibly subtidal environment suggests a second rapid subsidence event. The ${ }^{14} \mathrm{C}$ dates for this tectonic event $(1105 \pm 175$ and $2575 \pm 205$ calendar years BP) are both younger and older than recorded by Mathewes and Clague (1994) for their Tectonic Event 2 (1900 calendar years BP). Mathewes and Clague (1994) found that as with Tectonic Event 1, Tectonic Event 2 caused subsidence in various areas on southern Vancouver Island. The discrepancy between the recorded dates for this event at Montague Harbour and elsewhere in the area may indicate that the pebble unit was deposited over a long period with low sedimentation rates. The discrepancy could also be due to the nature of the dated material as one of the two ${ }^{14} \mathrm{C}$ dates was from a marine shell which can undergo significant reworking and when living, may burrow and possibly penetrate deeply into the sediment.

The upper three sedimentary units were lithologically similar, comprised primarily of sandy silts with large quantities of shell material of lower intertidal and subtidal bivalves (Unit 4; Fig. 2). As sea levels continued to gradually rise (Clague et al., 1982) shell middens in the embayment began to erode away. This shell material was then re-incorporated into the upper sediment units of the section. Foraminiferal concentrations dramatically increased within the uppermost three samples examined. The increase in abundance is probably the result of increased productivity associated with gradually deepening water, decreased sedimentation rates and perhaps more marine conditions.

The overall rise in sea level of approximately $5 \mathrm{~m}$ during the last 3500 years BP recorded in the stratigraphic section at Montague Harbour is quite consistent with the curve proposed by Clague et al. (1982) for the Victoria-Gulf Island region. Based on the application of this curve to our results, further investigations for relatively undisturbed Charles and older cultural sites should be conducted in deeper water (when sea level was -15 to $-6 \mathrm{~m}$ below present). Based on the present bathymetry of the harbor it seems that the $10 \mathrm{~m}$ bathymetric contour interval could represent an older paleoshoreline. Therefore, an area between the 5 and $10 \mathrm{~m}$ bathymetric contours may yield the desired older cultural sites (Fig. 7).

The preceding interpretation of the stratigraphic section from Montague Harbour is a working hypothesis based on the available foraminifera and macrofossil data and the gross sedimentological characters of the stratigraphic section. This interpretation will likely be enhanced with further information, but in the meantime it offers a useful framework within which further investigations can be conducted.

\section{CONCLUSIONS}

This combined micropaleontological/sedimentological study from Montague Harbour demonstrates the usefulness of micropaleontological techniques for the analysis of sea-level changes as they impact on nearshore archaeological sites. The analysis of the stratigraphic section seems to have determined two tectonic subsidence events in the sedimentary and paleontological record as represented at Montague Harbour. These two episodic events roughly match events re- 


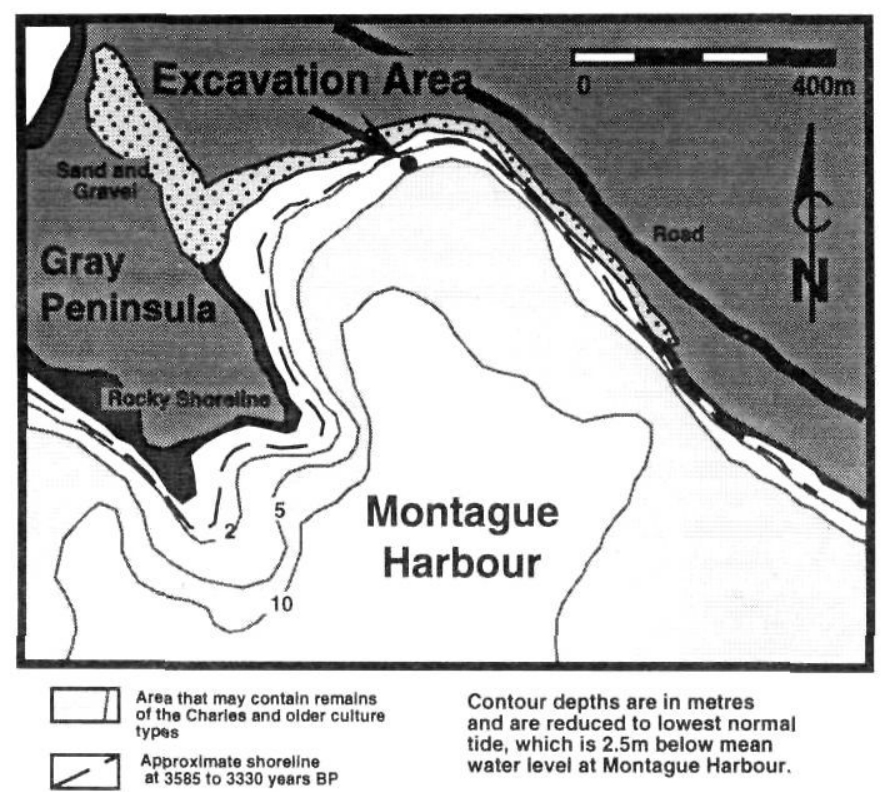

FIGURE 7. Proposed shoreline ( 3500 years BP) based on the stratigraphic section and the area that may potentially yield Charles type cultural sites. Map was derived from Canadian Hydrographic chart no. 3473 .

Extrapolation de la ligne de rivage de 3500 BP fondée sur la coupe stratigraphique et l'emplacement de la zone susceptible de livrer des vestiges de la culture Charles (issue de la carte hydrographique du Canada $n^{\circ} 3473$ ).

corded $35 \mathrm{~km}$ south near Victoria which have been associated with large interplate or intraplate earthquakes dated at 1900 and 3600 calendar years ago (Mathewes and Clague, 1994). These two events occurred during the overall gentle transgression proposed by Clague et al. (1982) for the late Holocene of the inner coastal and Gulf Island region. It is only because of this gentle transgression that the more dramatic tectonic events can be recognized within the stratigraphic section (Clague et al., 1982). These two events coupled with the general Holocene transgression caused a salinity shift in the environment within Montague Harbour through the erosion and opening of the northwestern channel. The opening of the channel allowed better mixing and interchange of marine water with fresh water runoff coming into the harbour. Pre- and post-opening sediments are characterized by two distinct foraminiferal biofacies.

Based on the ${ }^{14} \mathrm{C}$ dating and the interpreted sea-level changes recorded in the stratigraphic section it would be profitable to examine deeper water localities in order to find the older Charles coastal sites during the period of lower sea level.

Recommendations for further paleoenvironmental investigations at Montague Harbour would entail excavation and/or coring in the deeper part of the basin to provide a more complete record of the sea level history here since deglaciation.

\section{ACKNOWLEDGMENTS}

Research was partially supported by Natural Sciences and Engineering Research Council of Canada Research Grant to RTP (OGP0041665). We would like to thank Richard Hebda and David B. Scott for critically reviewing the manuscript and we would also like to thank all volunteers and staff that were involved in the excavation and to the following supporting institutions: The Underwater Archaeological Society of British Columbia, The Archaeological Society of British Columbia, The British Columbia Heritage Trust, The Canadian Department of Communication's Access to Archaeology Program, Yukon College, Kolhn-Leeonoff Co. Ltd., The University of British Columbia's Museum of Anthropology and the Vancouver Maritime Museum.

\section{REFERENCES}

Atwater, B.F., 1987. Evidence for great Holocene earthquakes along the outer coast of Washington State. Science, 236: 942-944.

1992. Geologic evidence for earthquakes during the past 2000 years along the Copalis River, Southern Coastal Washington. Journal of Geophysical Research, 97: 1901-1919.

Atwater, B.F., Stuiver, M. and Yamaguchi, D.K., 1991. Radiocarbon test of earthquake magnitude at the Cascadia subduction zone. Nature, 353: 156158.

Barrick, R.E., Beveridge, A.E., Patterson, R.T. and Schubert, J.K., 1989. Reexamination of the benthic foraminiferal fauna from a Late Pleistocene marine terrace deposit near Goleta, California. Journal of Paleontology, 63(3): 261-267.

Cushman, J.A. and Todd, R., 1947. Foraminifera from the coast of Washington. Cushman Laboratory of Foraminiferal Research Special Publication, 21: 1-23.

Cockbain, A.E., 1963. Distribution of foraminifera in the Juan de Fuca and Georgia Straits, British Columbia, Canada. Cushman Foundation for Foraminiferal Research, 14(2): 37-57.

Clague J.J., Harper, J.R., Hebda, R.J. and Howes, D.E., 1982. Late Quaternary sea levels and crustal movements, coastal British Columbia. Canadian Journal of Earth Sciences, 19: 597-618.

Cooper, W.C., 1961. Intertidal foraminifera of the California and Oregon coast. Contributions from the Cushman Foundation of Foraminiferal Research,12: 47-63.

Duff, W., 1963. Sea levels and archaeology on the northwest coast. Paper presented to the 16th Annual Meeting of the Northwest Anthropological Conference, Portland, Oregon.

Easton, N.A., 1988. Shoreline subsidence and rising sea levels: Implications for prehistoric underwater archaeology on the northwest coast. Paper presented to the Canadian Archaeological Association Annual Meetings, May 14th 1988, Whistler, British Columbia.

1991. Archaeology under the water at Montague Harbour. The Midden, 23(3): 1-4.

1992a. Mal de Mer over Terra Incognita: Or, "what ails the coastal migration theory?". Arctic Anthropology, 29(2): 28-41.

1992b. More findings from down under (the waters of Montague Harbour). The Midden, 24(3): 9-12.

1993. Underwater Archaeology in Montague Harbour - Interim. Report on the 1992 Field Excavations. Unpublished report submitted to Underwater Archaeological Society of British Columbia (B.C.), B.C. Heritage Trust, B.C. Archaeology Branch and the Canadian Department of Communications, $46 \mathrm{p}$.

Easton, N.A. and Moore, C.D., 1991. Test excavations of sub-tidal deposits at Montague Harbour, British Columbia, Canada - 1989. International Journal of Nautical Archaeology and Underwater Exploration, 20(4): 269-280.

Fairbanks, R.G., 1989. A 17,000-year glacio-eustatic sea level record: Influence of glacial melting rates on the Younger Dryas event and deep-ocean circulation. Nature, 342: 637-42.

Fedje, D. W., 1993. Sea-Levels and Prehistory in Gwaii Haanas. M.A. thesis University of Calgary, $160 \mathrm{p}$. 
Fishbein, E. and Patterson, R.T., 1993. Error-weighted maximum likelihood (EWML): A new statistically based method to cluster quantitative micropaleontological data. Journal of Paleontology, 67(3): 475-485.

Fladmark, K.R., 1979. Routes: Alternate migration corridors for early man in North America. American Antiquity, 44(1): 55-69.

1990. Possible early human occupation of the Queen Charlotte Islands, British Columbia. Canadian Journal of Archaeology, 14: 183-197.

Flemming, N.C., 1983. Survival of submerged lithic and bronze age artifact sites: A review of case histories, p. 135-173. in P.M. Masters and N.C. Flemming, eds., Quaternary Coastlines and Marine Archaeology: Towards the Prehistory of Land Bridges and Continental Shelves. Academic Press, London.

Flint, R.F., 1971. Glacial and Quaternary geology. John Wiley and Sons, New York, $892 \mathrm{p}$.

Gruhn, R., 1988. Linguistic evidence in support of the coastal route of earliest entry into the New World. Man, 23(1): 77-100.

Guilbault, J.P., Clague, J.J. and Lapointe, M., 1995. Amount of subsidence during a late Holocene earthquake - evidence from fossil tidal marsh foraminifera at Vancouver Island, west coast of Canada. Palaeogeography, Palaeoclimatology, Palaeoecology, 118: 49-71.

Hald, M. and Vorren, T.O., 1987. Foraminifera stratigraphy and environment of late Weichselian deposits on the continental shelf off Troms, northern Norway. Marine Micropaleontology, 12: 129-160.

Josenhans, H.W., Barrie, J.V., Conway, K.W., Patterson, R.T., Mathewes, R.W. and Woodsworth, G.J., 1993. Surficial geology of the Queen Charlotte Basin: Evidence of submerged proglacial lakes at $170 \mathrm{~m}$ on the continental shelf of western Canada. In Current Research, Part A Geological Survey of Canada, 93-1A: 119-127.

Josenhans, H.W., Fedje, D.W., Conway, K.W. and Barrie, J.V., 1995. Post glacial sea levels on the Western Canadian continental shelf: Evidence for rapid change, extensive subaerial exposure, and early human habitation. Marine Geology, 125: 73-94.

Lankford, R.R. and Phleger, F.B, 1973. Foraminifera from the nearshore turbulent zone, western North America. Journal of Foraminiferal Research 3: 101-132.

Luternauer, J.J., Conway, K.W., Clague, J.L. and Blaise, J.V., 1989. Late Quaternary geology and geochronology of the central continental shelf of Western Canada. Marine Geology, 89: 57-68.

Mathewes, R.W., 1994. Palynology as a technique for identifying Holocene earthquakes in coastal wetlands. Geological Society of America Annual Meeting, Abstracts with Programs, Seattle WA, October 24-27 1994, p. 529.

Mathewes, R.W. and Clague, J.J., 1994. Detection of Large Prehistoric Earthquakes in the Pacific Northwest by Microfossil Analysis. Science, 264: 688691.

Matson, R.G. and Coupland, G., 1995. The Prehistory of the Northwest Coast. Academic Press, New York, 364 p.

Miller, A.A.L., Scott, D.B. and Medioli, F.S., 1982. Elphidium excavatum (Terquem); Ecophenotypic versus subspecific variation. Journal of Foraminiferal Research, 12: 116-144.

Mitchell, D.H., 1971. Archaeology of the Gulf of Georgia Area: A natural region and its culture types. Syesis, 4(1): supplement 1.

1990. Prehistory of the coasts of southern British Columbia and Northern Washington, p. 340-358. In W. Shuttles, ed., Handbook of the North American Indians. Volume 7, Northwest Coast. Smithsonian Institute, Washington, D.C.

Monger, J.W.H. and Price, R.A., 1979. Geodynamic evolution of the Canadian Cordillera-progress and problems. Canadian Journal of Earth Sciences, 16: 770-791.
Patterson, R.T., 1993. Late Quaternary benthic foraminiferal biofacies and paleoceanography of Queen Charlotte Sound and Southern Hecate Strait, British Columbia. Journal of Foraminiferal Research, 23(1): 1-18.

Patterson, R.T. and Fishbein, E., 1989. Re-examination of the statistical methods used to determine the number of point counts needed for micropaleontological quantitative research. Journal of Paleontology, 63: 245248.

Patterson, R.T. and Cameron, B.E.B., 1991. Foraminiferal Biofacies Succession in the Late Quaternary Fraser River Delta, British Columbia. Journa! of Foraminiferal Research, 21(3): 228-243.

Patterson, R.T. and Luternauer, J.L., 1993. Holocene foraminiferal faunas from cores collected on the Fraser River delta, British Columbia: A paleoecological interpretation. In Current Research, Part A, Geological Survey of Canada, 93-1A: 245-254.

Reinhardt, E.G. Patterson, R.T. and Schröder-Adams, C., 1994a. Geoarchaeology of the Ancient Harbor site of Caesarea Maritima, Israel: Evidence from sedimentology and paleoecology of benthic foraminifera. Journal of Foraminiferal Research, 24:1: 37-49.

-1994b. The paleoecology of benthic foraminifera and marine archaeology: A case study from the ancient harbor of Caesarea Maritima, Israel. Science and Archaeology - Towards an Interdisciplinary Approach to Studying the Past, Conference Program and Abstracts, Harvard University, Cambridge, MA, October 14-16 1994.

Riddihough, R.P., 1977. A model for recent plate interactions off Canada's west coast. Canadian Journal of Earth Sciences, 14: 384-396.

Riddihough, R.P. and Hyndman, R. D., 1976. Canada's active western margin: The case for subduction. Geoscience Canada, 3: 269-278.

Scott, D.B., 1974, Recent benthonic foraminifera from Samish and Padilla bays, Washington. Northwest Science, 48(4): 211-218.

Sloan, D., 1980. Foraminifera of Sagamon (?) estuarine deposits beneath central San Francisco Bay, California, p. 1-12. In M.E. Field, R.G. Douglas, A.H. Bouma, J.C. Ingle and I.P. Coulburn, eds., Quaternary Depositional Environments of the Pacific Coast. Pacific Coast Paleogeography Symposium 4, April 9th 1980.

Souther, J.G., 1977. Volcanism and tectonic environments in the Canadian Cordillera - A second look, p. 3-24. In W.R.A Baragar, L.C. Coleman and J.M. Hall, eds., Volcanic Regimes in Canada. Geological Association of Canada, Special Paper No. 16.

Stuiver, M., Pearson, G. W. and Braziunas, T., 1986. Radiocarbon age calibration of marine samples back to $9000 \mathrm{cal}$ yr. BP. Radiocarbon, 28: 980121.

Stuiver, M. and Braziunas, T. F., 1993. Modeling atmospheric ${ }^{14} \mathrm{C}$ influences and ${ }^{14} \mathrm{C}$ ages of marine samples to 10,000 BC. Radiocarbon, 35: 137-189.

Stuiver, M. and Reimer, P. J., 1993. Extended ${ }^{14} \mathrm{C}$ data base and revised calib 3.0 14C age calibration. Radiocarbon, 35: 215-230.

SYSTAT, 1992. Statistics, Version 5.2 Edition. SYSTAT, Inc., Evanston, II, $724 \mathrm{p}$.

Thomson, G., 1978. Prehistoric settlement changes in the southern northwest coast: A functional approach. Reports in Archaeology No. 5, University of Washington, Seattle.

Wheeler, J.O., Aitken, J.D., Berry, M.J., Gabrielse, H., Hutchison, W.W., Jacoby, W.R., Monger, J.W.H., Niblett, E.R., Norris, D.K., Price, R.A. and Stacey, R.A., 1972. The Cordilleran Structural province, p. 1-81. In R.A. Price and R.J.W. Douglas, eds., Variations in tectonic styles in Canada. Geological Association of Canada, Special Paper No. 11.

Wetmore, K.L., 1987. Correlations between test strength, morphology and habitat in some benthic foraminifera from the coast of Washington. Journal of Foraminiferal Research, 17(1): 1-13. 